\title{
ENERGY CONSUMPTION REDUCTION IN BUILDINGS THROUGH APPLYING GREEN ROOFS
}

\author{
Yasaman Saharkhiz \\ Department of Architecture, Engineering Faculty, Islamic Azad University- North Tehran Branch, \\ Tehran, Iran \\ Majid Valizadeh \\ Department of Civil Engineering, Tech and Engineering Faculty, Islamic Azad University, Sanandaj \\ Branch, Sanandaj, Iran
}

\begin{abstract}
Green roof technology has a history that predates the modern era. Many functions of green roofs utilized during human history are analogous to contemporary functions. The justification of the use of green roof technology based on a review of literature shows the multiple and documented benefits that these systems can impart to the urban environment. Green Roofs can save energy, reduce neighborhood temperatures, and protect human health. They have a strong regulating effect on the temperature of underlying roof surfaces and building interiors, reducing the energy needed for building cooling and the effects of the urban heat island effect.
\end{abstract}

Keywords: Green Roofs, Energy Conservation, Heat Transfer, Insulation

\section{INTRODUCTION}

Considering rising energy price, its impact on consumption, creating motivation for efficiency and increasing its yield, moved researchers to investigate about plant's effect on energy consumption reduction. In addition, due to increasing in population and lack of adequate land for construction, building density in large cities has increased. This high density has caused lots of negative effects. The urban heat island effect that makes the average temperature in the city is higher than normal, is one of them. This increase in temperature causes an increase in energy consumption for cooling [1].

Green roofs offer a wide range of sustainability benefits, from water attenuation to climate change adaptation. Standard 'off the shelf' products, which tend to be sedum based green roofs, can provide some benefit for invertebrates and other wildlife. Furthermore, it can also provide benefits associated with green infrastructure, improved building performance and amenity.

Solar radiation hits the black tar of the conventional roof and is transferred into heat on a large scale; urban centers create a microclimate of hotter weather called the urban heat island effect. Green roofs reduce the urban heat island effect by providing a substrate for evapotranspiration and altering the surface reflection. A reduction to the urban heat island effect indirectly reduces building cooling demands [2]. Intuitively, one roof will not affect urban heat island effect on a citywide scale; only with massive installation would this benefit be realized. A green roof can cost double that of a traditional roof due to engineering and installation costs, yet it will pay for itself over time in savings for a replacement roof and on lower cooling costs over the life of the green roof. The energy savings of a green versus that of a conventional roof are from the insulating properties of a vegetated structure, evapotranspiration from the vegetation, and the substrate acting as a thermal mass [3].In simulations, green roofs protect buildings from solar radiation through the combined effects of shielding, insulation and evapotranspiration cooling to passively cool. Green roof plant materials absorb radiant solar energy to fuel photosynthesis, with added heat radiation from higher plant structure [4]. The insulating abilities of green roofs in summer have 
been quantified and they reduce the heat flux in a building. Green roofs lower surface temperatures, and the substrate acts as insulation [5].

\section{HISTORY}

Green roofs and roof gardens date back to thousands of years. Early evidence of roof gardens includes the mausoleums of Augustus and Hadrian. In Russia, hanging gardens were favored in the seventeenth century Kremlin. In the twentieth century, green roofs and hanging gardens were established on homes in many countries [6]. The oldest roof garden appears to be the ziggurats of ancient Mesopotamia, built from the fourth millennium until $600 \mathrm{BCE}^{1}$ Located in the court yards of temples in major cities, the ziggurats were great stepped pyramid towers of stone, built in stages. The best preserved of the ancient ziggurats is that of Nanna, in the ancient city of Ur, built by Ur-Nammu, and his son, Shulgi, who reigned from 21132047B.C.E. King Nebuchadnezzar II, to console his wife, Amytis, constructed the Hanging Gardens of Babylon. During the Middle Ages and the Renaissance, roof gardens were owned by the rich, and by Benedictine monks. From the 1600s to 1800 s, Norwegians used soil on roofs as insulation, utilizing grasses and other species to hold the soil in place. Early American settlers of the Great Plains also used this technique in the late 1800s due to timber scarcity [7]. Archaeology has revealed the green roofs of the Middle Ages. In this period, plant materials were derived from local sod. A substrate/water retention membrane from inverted sod layers, and birch bark as a water-proofing layer, supported by roof boards and wooden beams [8]. In 1856, Robert Chambers of England visited Iceland and the Faeroe Islands, he wrote of timber scarcity in the Faeroes, concerning a log washed up on the beach, he called it a "windfall of no common value" [9].The buildings found in Vinland, produced by the Vikings are of two main forms. They were large multi-roomed structures, known as halls, and interpreted as houses with a workshop. Constructed of turf sods laid against a timber framework, and paneled with wood on their inner faces, they had a central hearth. The roofs were also made of turf sods, resting on an underlay of branches supported by timbers. These houses could have housed 70 to 90 people [10].In the early 1960s terraced green roof technologies were researched and developed in many countries, namely Switzerland and Germany. Reinhard Bornkamm, a German researcher published his work on green roofs in 1961. In 1969, the GENO Hauswas built in Germany, and remained functional until 1990 (metropolis magazine). In the 1970s a significant amount of technical research on the different components of green roofing technology was carried out including studies on root repelling agents, waterproof membranes, drainage, light-weight growing media and plants [11].Currently, green roofs are becoming more common in the United States, although other countries are farther along in the adoption of green roof systems. In Germany for example, it is estimated that $14 \%$ of all flat roofs are green [12].Today there are many green roofs all around the world.

\section{STUDY PROCEDURE}

In this study, based on Logical reasoning and concepts deduction the role of green roofs in energy conservation is discussed. Therefore, Research Methodology is done based on Analytical method.

\section{ENERGY SAVING THROUGH HEAT TRANSFER REDUCTION}

Green roofs reduce energy consumption for heating and cooling. Of the total solar radiation that is received by the green roof, $27 \%$ will be reflecting and $60 \%$ is absorbed by the plant and $13 \%$ penetrates into the soil [13].

Studies carried out in the National Research Center in Canada have shown that green roof can decrease Heat flow in roof $70-90 \%$ in summer and $10-30 \%$ in winter and lower Energy consumption about $75 \%$ [14]. Considering that heat transfers through areas and bodies with higher temperature to with lower temperatures, so heat transfers on roofs from inside to outside in the winter and from outside to inside in summer, but The amount of impact varies according to the season and humidity levels.

\footnotetext{
${ }^{1}$ Before Common Era
}

Submit Date: 11.06.2016, Acceptance Date: 23.07.2016, DOI NO: 10.7456/1060AGSE/051

Copyright $(\mathbb{C}$ The Turkish Online Journal of Design, Art and Communication 


\section{HEAT TRANSFER IN SUMMER}

Green roof layers help cooling space under the roof through reduction of the heat variability and increasing heat capacity of roof layers and vegetation, also by shading, maintaining moisture and photosynthesis. The combination of reactions in soil, photosynthesis and Sweating and transpiration of the plants causes absorbed solar energy reduction by roof layers. Studies on green roofs show that most cooling benefits in summer are due to roof Sweating and transpiration [15].

The plant transpiration rates depends on various factors such as the type of leaf or stalk, root structure, light intensity, soil moisture, and so on. For instance, shadow effect on vegetation can be terrific. Ghosting of the herb on the roof surface causes prevention of roof temperature increase. Nottingham University research about the temperature of the space under typical roof and green roof in summer indicates that if an average temperature is $18.4^{\circ} \mathrm{C}$, the temperature of space under typical roofs will be $32{ }^{\circ} \mathrm{C}$ and under green roofs will be $17.1{ }^{\circ} \mathrm{C}[16]$.

Mineral surfaces such as buildings and standard roofs cause an increase in the temperature of city and heat island effect. Lack of plants and existence of high- rise buildings; prevent weather natural cooling of city. As a result, the temperature of city reaches to more temperature than their surroundings (figure 1).

Roof covering by plants leads to reduction in city temperature and then reduce energy consumption. Columbia University study has shown that if $59 \%$ of the roof of city buildings changed for green roof, the average of Colombia temperature will decrease $1{ }^{\circ} \mathrm{C}$.

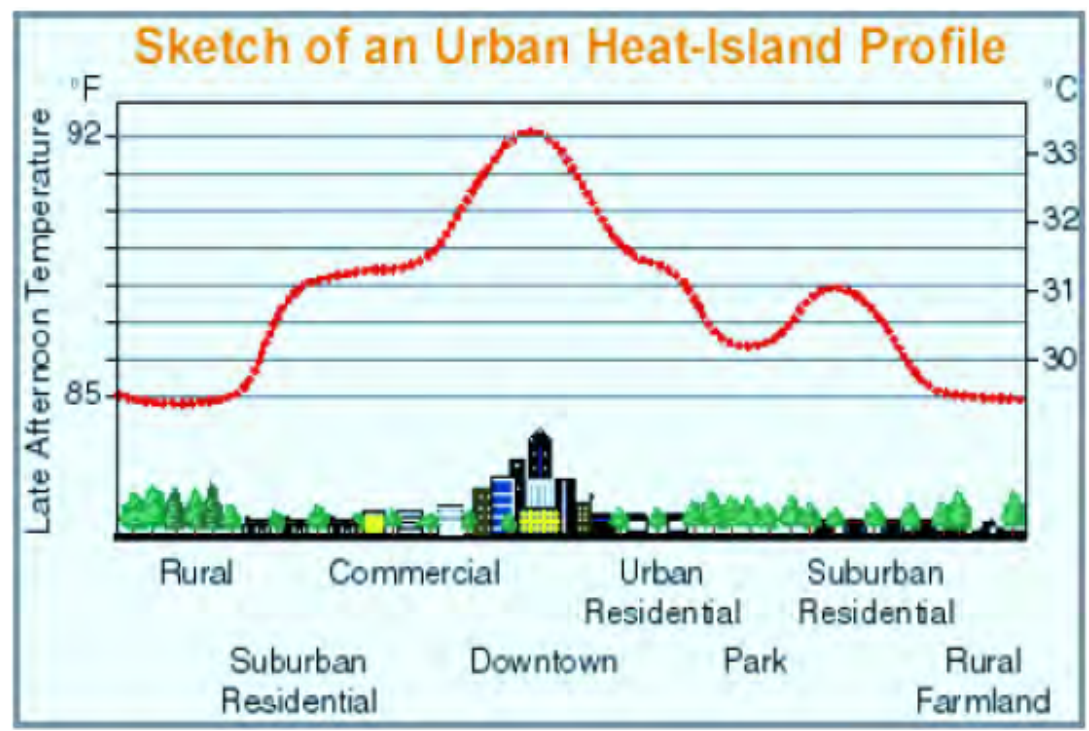

Fig. 1. Heat island effect in cities display

\section{HEAT TRANSFER IN WINTER}

In addition to increasing building heat capacity, Green Roof by increasing layers of roof, through insulation of the building (vegetation and soil) and decreasing wind speed, makes building insulated against cold weather and reduces energy consumption for heating plant roots hold steady some air among themselves, which acts as a thermal insulation layer. Surely, Performance of the thermal insulation layer in green roofs depends on the amount of retained moisture in them. The more moisture quantity is, the less efficiency gets [16].

Results of a study at the University of Toronto showed that green roofs in cold climates also are effective to keep the weather warm. The study shows the effects of green roofs to reduce the intensity of wind is more than the effects of its shading. In winter vegetation prevents planting area freezing and increases the 
amount of roof insulation. If the vegetation on intense green roofs covered with frost or snow, it would be more effective [15]. Trent University in Peterborough, Canada research about atmosphere temperature under a typical and green roof in winter shows that if the average daily temperature on a winter day is 0 ${ }^{0} \mathrm{C}$, then the weather temperature under typical roof is $0.2{ }^{\circ} \mathrm{C}$ and under green roof is $4.7{ }^{\circ} \mathrm{C}$, and it shows the effect of green roofs on heat transfer [16].

\section{RESULTS}

Number of floor (height) on green roof system is installed and usage of building when green roof system is applied. When it is attempted to save heating energy by green roof system, it is more efficient to apply the system to the region with low temperature. In addition, when the region has high temperature during summer, so the formation of shade on top roof and transpiration effect due to green roof system, contribute to considerable conservation of cooling energy. When it comes to the building usage, if green roof system is applied, it turned out that heating/cooling energy conservation vary by the usage of building. It is because of different running hours of cooling energy by usage. By building usage, running hour was set from 16:00 to 05:00 next day for residential building; from 07:00 to 19:00 for office building; from 08:00-18:00 for educational building; and from 09:00 to 18:00 for commercial building. Moreover, insulation effect by the installation of green roof system turned out greater during nighttime zone than daytime zone because the load of cooling system is greater to keep indoor temperature low for bedtime. Furthermore, a residential building has greater benefit from cooling energy conservation by green roof system than the other usages of building. Although large store or office building consume more cooling energy due to more occupants and electric devices in use, so they have higher level of internal heat values than a residential building. However, commercial and office building cannot discharge heat created from inside efficiently because the insulation effect of roof layer due to the increased thickness of soil on roof is greater than the cooling energy conservation effect by the shades and transpiration of roof floor (green roof system). Also, cooling/heating energy conservation effect turned out to be varied by (height of) floor on which green roof system is installed. When green roof system is applied on the top of a single-story building, its effect was the greatest and it weakens as the number of floor goes up. It is because that a single-story building does not cooling/heating conditioning system below and connected to the ground surface, so it has high level of internal load. As a result, heating energy conservation effect is great. As a building gets taller (5-storied, 10-storied and 15-storied building), it has faster wind speed, which more activates soil to evaporate moisture. It improves cooling effect and thus insulation effect weakens [17].In multi story buildings there are energy demand reductions in only the top floors. The two highest floors below a green roof have the greatest benefit, floors greater than four stories from the roof are not impacted [2].Green roofs save energy for buildings from both ecological and social points of view; the central issue is improving the thermal regime of buildings. Individual buildings with improved comfort would decrease the need for air conditioning and heating. Widespread installation of green roofs could mitigate the harsh aspects of the urban heat island effect [4].

\section{CONCLUSION}

Applying of a green roof can improve the insulation properties of a building that is why annual energy consumption can be reduced. Not only does the roof act to reduce the heat loss from the building in winter and heat gain into the building in summer, it also adds thermal mass to help stabilize internal temperatures year round. Many studies exist that assess the potential energy savings of green roofs when added to buildings. This suggests that green roofs are predominately seen as a passive cooling technique, rather than as a thermal insulator in the winter. Potential winter heating savings have however been investigated, although not to the extent of summer cooling.

\section{REFERENCE}

http://epa.gov/heatisland/strategies/gre enroofs.html

Blackhurst, M. (2010). Cost Effectiveness of Green Roofs. Journal of Architectural Engineering, 16(4), 136-143.] 
Snodgrass, E. C., \& Snodgrass, L. L. (2006). Green roof plants: a resource and planting guide. Portland, Origin: Timber Press.

Hongming, H., \& Jim, C. (2010). Simulation of Thermodynamic Transmission in the Green Roof Ecosystem. Ecological Modelling, 221, 2949-2958.

Hao, N. (2011). Scaling of Economic Benefits from Green Roof Implementation in Washington, DC. Environmental Science Technology, 44, 4302-4308.

Callaghan, C., Kuhn, M., \& Bass, B. (1999). Greenbacks from Green Roofs: Forging a New Industry in Canada. Canada Mortgage and Housing Corporation, 11-12.

Hammer, K. (1968). North Dakota History: 1870-1889 (1st ed., Vol. 35). ND.

http://www.hurstwic.org/history/articles/daily living/text/Turf Houses.htm

Chambers, R. (1856). Tracings of Iceland \& the Faroe Islands. London and Edinburgh: W. \& R. Chambers.

Hall, R. (2007). Exploring the World of the Vikings. London: Thames \& Hudson.

Peck, S., Callaghan, C., Kuhn, M., \& Bass, B. (1999). Greenbacks from Green Roofs: Forging a New Industry in Canada. Canada Mortgage and Housing Corporation, 11-12.

Getter, K., \& Rowe, B. (2006). The Role of Extensive Green Roofs in Sustainable Development. Horticulture Science, 41(5), 1276-1285.

Ryerson University. (2005). Report on the Environmental Benefits and Costs of Green Roof Technology for the City of Toronto, Retrieved from http://www.toronto.ca/greenroofs/pdf/chapter2.pdf

Liu, K. \& Bass, B. (2005). Performance of Green Roof Systems. Canada: National Research Council Canada.

Oberndorfer, E., Lundholm, J., Bass, B., Coffman, R. R., Doshi, H., Dunnett, N., Gaffin, S., Köhler, M., Liu, K. KY, Bradley Rowe, D. (2007). Green Roofs as Urban Ecosystems: Ecological Structures, Functions, and Services, Journal of Bioscience, 57, 823-833. Retrieved from http://digitalcommons.ryerson.ca/arch/1

Environmental Advantages of Green Roof, (2010). Retrieved from http://www.efbgreenroof.eu/verband/fachbei/fa01 englisch.html

Hyeong Min Park, S., Seongu, D.Y.C., (2014), Heating and Cooling Energy Conservation Effects by Green Roof Systems in Relation with Building Location, Usage and Number of Floors, KIEAE Journal, Vol. 14, No. 2., pp. 11-19. 